\title{
Deinococcus aquaticus sp. nov., isolated from fresh water, and Deinococcus caeni sp. nov., isolated from activated sludge
}

\author{
Correspondence \\ Wan-Taek Im \\ wandra@kaist.ac.kr \\ Sung-Taik Lee \\ e_stlee@kaist.ac.kr
}

\author{
Wan-Taek Im, ${ }^{1}$ Hae-Min Jung, ${ }^{1}$ Leonid N. Ten, ${ }^{2}$ Myung Kyum Kim, ${ }^{1,3}$ \\ Nagamani Bora, ${ }^{4}$ Michael Goodfellow, ${ }^{4}$ Sangyong Lim, ${ }^{5}$ Jinwoo Jung ${ }^{5}$ \\ and Sung-Taik Lee ${ }^{1}$
}
${ }^{1}$ Environmental and Molecular Microbiology Lab, Department of Biological Sciences, Korea Advanced Institute of Science and Technology (KAIST), Guseong-dong 373-1, Yuseong-gu, Daejeon 305-701, Republic of Korea
${ }^{2}$ Department of Biology and Medicinal Science, Pai Chai University, 14 Yeonja-1-Gil, Seo-Gu, Daejeon 302-735, Republic of Korea
${ }^{3}$ Dept of Oriental Medicinal Material and Processing, College of Life Science, Kyung Hee University, 1 Seocheon, Kihung Yongin, Kyunggi 449-701, Republic of Korea
${ }^{4}$ School of Biology, King George VIth Building, University of Newcastle, Newcastle upon Tyne NE1 7RU, UK
${ }^{5}$ Radiation Food Science and Biotechnology Team, Advanced Radiation Technology Institute, Korea Atomic Energy Research Institute, Jeongup 305-600, Republic of Korea

The availability of improved taxonomic procedures facilitates the preliminary characterization of relatively large numbers of bacteria from environmental samples and hence the recognition of novel species. Over 100 putatively novel species were highlighted in our labor-

The GenBank/EMBL/DDBJ accession numbers for the $16 \mathrm{~S}$ rRNA gene sequences of strains $\mathrm{PB} 314^{\top}$ and $\mathrm{Ho}^{-}-08^{\top}$ are respectively DQ0 17708 and DQ017709.

A 16S rRNA gene sequence-based maximum-likelihood tree, results of 2D TLC of polar lipids of strains $\mathrm{PB} 314^{\top}$ and $\mathrm{Ho}-08^{\top}$ and a comparison of fatty acid profiles are available as supplementary material with the online version of this paper. atory following the characterization of 300 aerobic phototrophic bacteria isolated from water and sediment samples collected either from the River Gapcheon, near Daejeon City, South Korea, or from a tributary of the river. One of the isolates, strain PB314, was tentatively assigned to the genus Deinococcus (unpublished results). A second strain, isolate Ho-08, was also considered to belong to the genus Deinococcus following the characterization of 128 bacterial strains isolated from activated sludge, compost and soil collected in the vicinity of Daejeon City in a second study designed to find novel bacterial species (Im et al., 2003). 
The genus Deinococcus was established by Brooks \& Murray (1981), and at present the genus comprises 27 species with validly published names. Although the $16 \mathrm{~S}$ rRNA gene sequence similarity may be considered low enough to differentiate some species into other genera, the genus Deinococcus has not been divided because of the common characteristics of its members. Species of the genus Deinococcus are strictly aerobic, have high resistance to ionizing radiation, produce reddish, pink or yellow colonies, generally stain Gram-positive, have L-ornithine in the peptidoglycan and lack teichoic acids (Brooks \& Murray, 1981; Ferreira et al., 1997; Rainey et al., 1997, 2005; Hirsch et al., 2004; Suresh et al., 2004; de Groot et al., 2005; Lai et al., 2006; Shashidhar \& Bandekar, 2006; Weon et al., 2007). 16S rRNA gene sequence analyses show that the deinococci form a phylogenetically diverse group in a deeply branching lineage within the Bacteria (Rainey et al., 1997, 2005).

The aim of the present study was to determine the taxonomic positions of two environmental isolates using a polyphasic approach. The resultant data indicated that isolates $\mathrm{PB} 314^{\mathrm{T}}$ and $\mathrm{Ho}-08^{\mathrm{T}}$ merit recognition as representatives of novel species of Deinococcus.

Strain $\mathrm{PB} 314^{\mathrm{T}}$ was isolated from a freshwater stream of the River Gapcheon via direct plating onto 1:10-diluted R2A agar (Difco). Strain Ho- $08^{\mathrm{T}}$ was isolated via direct plating onto R2A agar from an activated sludge in a wastewatertreatment plant that was constructed to treat the leachate flow from the landfill of Daejeon city. Colonies were subcultured from the isolation plates onto R2A agar plates and routinely cultured on $\mathrm{R} 2 \mathrm{~A}$ agar at $30{ }^{\circ} \mathrm{C}$ and maintained as glycerol suspensions $(20 \%, \mathrm{w} / \mathrm{v})$ at $-70{ }^{\circ} \mathrm{C}$. Purified colonies were tentatively identified by using partial $16 \mathrm{~S}$ rRNA gene sequences.

Genomic DNA was extracted and purified from each of the isolates using a commercial DNA extraction kit (Core Biosystem); PCR-mediated amplification of the 16S rRNA gene and sequencing of purified PCR products were carried out according to Kim et al. (2005). The resultant 16S rRNA gene sequences, compiled using SeqMan software (DNASTAR), were aligned using the BioEdit program (Hall, 1999), with corresponding sequences drawn from GenBank. Multiple alignments were performed by CLUSTAL_X program (Thompson et al., 1997) and gaps were edited in the BioEdit program (Hall, 1999). Evolutionary distances were calculated using Kimura's two-parameter model (Kimura, 1983). Phylogenetic trees were constructed by using the neighbourjoining method (Saitou \& Nei, 1987) and maximumparsimony (Fitch, 1971) methods in the MEGA3 suite of programs (Kumar et al., 2004) and the maximum-likelihood method with the PHYLIP package (Felsenstein, 1989). Unrooted tree topologies were evaluated by bootstrap analyses (Felsenstein, 1985) based on 1000 replicates taken from the neighbour-joining database.

Nearly complete 16S rRNA gene sequences of strains $\mathrm{PB} 314^{\mathrm{T}}$ and $\mathrm{Ho}-08^{\mathrm{T}}$ (1459 and $1458 \mathrm{bp}$, respectively) were obtained. Preliminary sequence comparison against $16 \mathrm{~S}$
rRNA gene sequences deposited in GenBank indicated that our isolates belong to the genus Deinococcus of the class Deinococci (data not shown). On the basis of 16S rRNA gene sequence similarity, the closest cultured relatives were Deinococcus grandis DSM $3963^{\mathrm{T}}$ (96.3 and $96.7 \%$, respectively) and Deinococcus indicus $\mathrm{Wt} / 1 \mathrm{a}^{\mathrm{T}}$ (96.3 and $96.4 \%$, respectively) and the sequence similarity to the remaining Deinococcus type strains was less than $95 \%$.This relationship between our isolates and other members of the genus Deinococcus was also evident in the phylogenetic trees (Fig. 1 and Supplementary Fig. S1, available in IJSEM Online). The sequences of the two strains showed high similarity (98.1\%), necessitating DNA-DNA hybridization tests.

The Gram reaction was performed using the non-staining method, as described by Buck (1982). Cell morphology and motility were observed under a Nikon light microscope at $\times 1000$, with cells allowed to grow on R2A agar for 3 days at $30{ }^{\circ} \mathrm{C}$. Catalase activity was determined by assessing bubble production in $3 \%(\mathrm{v} / \mathrm{v}) \mathrm{H}_{2} \mathrm{O}_{2}$; oxidase activity was determined using $1 \%(\mathrm{w} / \mathrm{v})$ tetramethyl-p-phenylenediamine. Substrate utilization as sole carbon sources and some physiological characteristics were determined using the API $32 \mathrm{GN}$ and API 20NE galleries according to the instructions of the manufacturer (bioMérieux). Anaerobic growth was determined in serum bottles containing R2A broth supplemented with thioglycolate $\left(1 \mathrm{~g} \mathrm{l}^{-1}\right)$ in which the upper air layer had been replaced with nitrogen. Nitrate and nitrite reduction were later confirmed by inoculating $25 \mathrm{ml}$ serum bottles in triplicate, each containing $13 \mathrm{ml}$ R2A broth, supplemented with $\mathrm{KNO}_{3}(10 \mathrm{mM})$ or $\mathrm{NaNO}_{2}$ $(10 \mathrm{mM})$, respectively. Tests for degradation of DNA [in which DNase agar (Scharlau) plates were flooded with $1 \mathrm{M}$ HCl], casein, starch (Atlas, 1993), lipid (Kouker \& Jaeger,

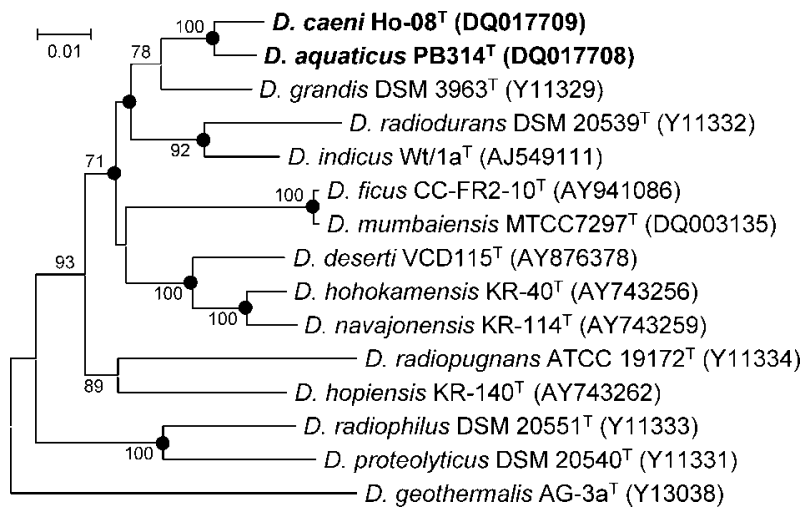

Fig. 1. Neighbour-joining phylogenetic tree based on 16S rRNA gene sequences showing relationships between isolates $\mathrm{Ho}^{-0} 8^{\top}$ and PB3 $14^{\top}$ and representatives of the genus Deinococcus. Dots indicate phyletic lines that were also recovered using the maximum-parsimony algorithm. Numbers at nodes indicate percentages of bootstrap support based on a neighbour-joining analysis of 1000 resampled datasets; only values above $70 \%$ are given. Bar, 0.01 substitutions per nucleotide position. 
1987), xylan and cellulose (Ten et al., 2004) were performed and evaluated after 5 days. Growth at different temperatures $\left(4,15,20,25,30,37\right.$ and $\left.42{ }^{\circ} \mathrm{C}\right)$ and various $\mathrm{pH}$ values ( $\mathrm{pH} 5.0-10.0$; at intervals of $0.5 \mathrm{pH}$ units) was assessed after incubation for up to 5 days. Salt tolerance was tested on R2A medium supplemented with $1-10 \%(\mathrm{w} /$ v) $\mathrm{NaCl}$ after 5 days incubation. Growth on nutrient agar, trypticase soy agar (TSA; Difco) and MacConkey agar was also evaluated, at $30{ }^{\circ} \mathrm{C}$.

To determine the survival rate after exposure to gamma radiation, cultures were grown at $30{ }^{\circ} \mathrm{C}$ in liquid nutrientrich medium TGY ( $1 \%$ tryptone, $0.1 \%$ glucose, $0.5 \%$ yeast extract) or on TGY solid medium. To measure ionizing radiation resistance, cultures grown to the early stationary phase $\left(\sim 10^{9}\right.$ cells $\left.\mathrm{ml}^{-1}\right)$ were divided into $1 \mathrm{ml}$ aliquots without change of broth and were exposed on ice to a cobalt-60 gamma irradiator (point source; AECL, IR-
79). The source strength was approximately $100 \mathrm{kCi}$ at a dose rate of $70 \mathrm{~Gy} \mathrm{~min}^{-1}$, and the actual doses were within $2 \%$ of the target dose. Irradiated cells were diluted, plated in triplicate on TGY agar plates and incubated for 2 days before survivors were scored.

Colonies of strain PB314 ${ }^{\mathrm{T}}$ cultured on R2A agar (Difco) at $30{ }^{\circ} \mathrm{C}$ were reddish, convex and circular. After 2 days incubation at $30{ }^{\circ} \mathrm{C}$ on R2A agar, colonies of strain Ho- $08^{\mathrm{T}}$ were pink and circular. Cells of both strains were aerobic, Gram-negative, non-motile rods. Strains $\mathrm{PB} 314^{\mathrm{T}}$ and Ho$08^{\mathrm{T}}$ were able to grow at $20-37{ }^{\circ} \mathrm{C}$, but did not grow at 4 or $42{ }^{\circ} \mathrm{C}$. Growth at $30{ }^{\circ} \mathrm{C}$ was also observed on nutrient agar, but not on TSA or MacConkey agar. Physiological characteristics of strains $\mathrm{PB} 314^{\mathrm{T}}$ and $\mathrm{Ho}-08^{\mathrm{T}}$ are summarized in the species descriptions and a comparison of selected characteristics with related type strains is shown in Table 1. Variation in the assimilation of various sole

Table 1. Chemotaxonomic and phenotypic properties that separate isolates $\mathrm{Ho}-08^{\top}$ and $\mathrm{PB} 314^{\top}$ from the type strains of phylogenetically close Deinococcus species

Strains: 1, PB314 ${ }^{\mathrm{T}} ; 2$, Ho- $08^{\mathrm{T}} ; 3$, D. grandis DSM $3963^{\mathrm{T}}$ (unless indicated, data from Suresh et al., 2004); 4, D. indicus MTCC4913 ${ }^{\mathrm{T}}$ (Suresh et al., 2004; Weon et al., 2007); 5, D. radiodurans ATCC $13939^{\mathrm{T}}$ (Battista \& Rainey, 2001; Rainey et al., 2005). All strains are Gram-negative, non-motile, rod-shaped bacteria that produce catalase and utilize maltose, sucrose and L-proline as sole carbon sources. None of the strains hydrolyses urea or assimilates L-rhamnose, L-alanine, acetate or citrate as sole carbon sources. +, Positive; -, negative; ND, no data available.

\begin{tabular}{|c|c|c|c|c|c|}
\hline Characteristic & 1 & 2 & 3 & 4 & 5 \\
\hline Colony colour & Red & Pink & Red & Red & Pink-red \\
\hline Temperature growth range $\left({ }^{\circ} \mathrm{C}\right)$ & $20-37$ & $20-37$ & $<30-42$ & $20-37$ & $>20$ to $<45$ \\
\hline Tolerance to $\mathrm{NaCl}(\% \mathrm{w} / \mathrm{v})$ & $0-3$ & $0-3$ & $0-1$ & $0-1$ & ND \\
\hline Oxidase & + & - & + & + & ND \\
\hline$\beta$-Galactosidase & + & + & + & + & - \\
\hline Nitrate reduction & - & - & + & + & + \\
\hline Arginine dihydrolase & - & - & - & + & ND \\
\hline Aesculin hydrolysis & + & - & + & + & - \\
\hline Gelatin hydrolysis & - & - & + & + & ND \\
\hline \multicolumn{6}{|l|}{ Utilization as carbon source of: } \\
\hline L-Arabinose & - & - & - & + & - \\
\hline Melibiose & + & - & - & + & ND \\
\hline D-Glucose & + & + & + & - & + \\
\hline D-Mannose & + & - & - & + & + \\
\hline D-Ribose & - & - & - & - & + \\
\hline Gluconate & + & + & - & + & ND \\
\hline Lactate & - & - & - & - & + \\
\hline L-Histidine & - & - & - & + & $\mathrm{ND}$ \\
\hline Malate & + & - & + & + & + \\
\hline D-Mannitol & + & - & + & - & $\mathrm{ND}$ \\
\hline D-Sorbitol & + & - & + & + & ND \\
\hline$N$-Acetyl-D-glucosamine & + & + & - & + & + \\
\hline Salicin & + & - & - & + & ND \\
\hline Peptidoglycan type & L-Orn-Gly ${ }_{2}$ & L-Orn-Gly ${ }_{2}$ & $\mathrm{~L}-\mathrm{Orn}-\mathrm{Gly}_{2}{ }^{*}$ & L-Orn & L-Orn-Gly $2-3$ \\
\hline Predominant fatty acids & $\begin{array}{c}\mathrm{C}_{16: 1} \omega 7 c \\
\mathrm{C}_{16: 0}\end{array}$ & $\begin{array}{c}\mathrm{C}_{16: 1} \omega 7 c \\
\mathrm{C}_{16: 0}\end{array}$ & $\begin{array}{c}\mathrm{C}_{15: 1}, \mathrm{C}_{16: 1} \omega 7 c \\
\mathrm{C}_{17: 1}\end{array}$ & $\begin{array}{c}\mathrm{C}_{16: 1} \omega 7 c, \mathrm{C}_{15: 1}, \\
\mathrm{C}_{16: 0}\end{array}$ & $\begin{array}{c}\mathrm{C}_{16: 1} \omega 7 c, \mathrm{C}_{16: 0}, \\
\mathrm{C}_{17: 1} \omega 8 c\end{array}$ \\
\hline DNA G $+C$ content $(\mathrm{mol} \%)$ & 68.3 & 68.4 & $68.4-69.4 \dagger$ & 65.8 & 67.0 \\
\hline
\end{tabular}

${ }^{\star}$ Data from Oyaizu et al. (1987) and Suresh et al. (2004).

$\dagger$ Range of values for four strains. 
carbon sources, in the hydrolysis of gelatin and in nitrate reduction was found between the two strains and their phylogenetically closest relatives of the genus Deinococcus.

It is evident from the representative survival curves (Fig. 2) that the isolates are much more sensitive than the control strain to gamma radiation. Survival rates following exposure to $3 \mathrm{kGy}$ were 7,4 and $88 \%$, respectively, for isolates $\mathrm{Ho}-08^{\mathrm{T}}, \mathrm{PB} 314^{\mathrm{T}}$ and Deinococcus radiodurans $\mathrm{R} 1$. Isolate $\mathrm{Ho}-08^{\mathrm{T}}$ was approximately ten times more sensitive than strain $\mathrm{PB} 314^{\mathrm{T}}$ to radiation doses of 9 and $15 \mathrm{kGy}$. Neither of the isolates demonstrated the characteristic shoulder of resistance in survival curves shown by highly resistant bacteria such as $D$. radiodurans (Battista et al., 1999). Radiation resistance is one of the main characteristics of the genus Deinococcus. For this reason, UV or gamma radiation has been used to isolate most organisms of the genus Deinococcus (Rainey et al., 2005; Oyaizu et al., 1987). However, a few novel species have been isolated from non-irradiated samples from air, soil, hot springs and culture contamination (Ferreira et al., 1997; Lai et al., 2006; Shashidhar \& Bandekar, 2006; Weon et al., 2007). Isolation of strains $\mathrm{Ho}-08^{\mathrm{T}}$ and $\mathrm{PB} 314^{\mathrm{T}}$, with relatively low resistance to radiation, demonstrates that the extreme radiation resistance of the organisms is not a result of selection of resistant strains by irradiation but is a normal characteristic, as defined by Mattimore \& Battista (1996). Significant difference in resistance to radiation strongly supports the suggestion that strains $\mathrm{Ho}-08^{\mathrm{T}}$ and $\mathrm{PB} 314^{\mathrm{T}}$ were differentiated from other species within the genus Deinococcus.

Chemotaxonomic studies were carried out to establish whether the isolates had chemical markers that supported their assignment to the genus Deinococcus. Preparation of the cell wall and determination of peptidoglycan structure were carried out by the methods described by Schleifer \& Kandler (1972) and cell-wall sugar analysis was carried out as described by Staneck \& Roberts (1974). Isoprenoid

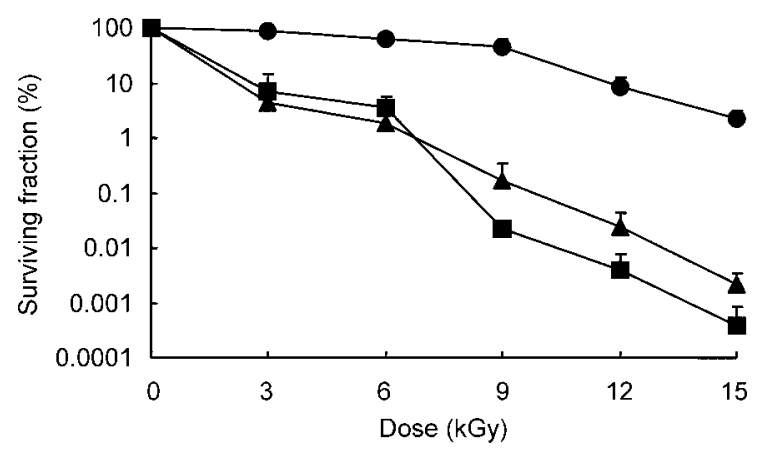

Fig. 2. Representative survival curves for strain $\mathrm{PB} 314^{\top}(\mathbf{\Lambda})$ and strain $\mathrm{Ho}^{-08}{ }^{\top}(\boldsymbol{\square})$ following exposure to gamma radiation. Survival of $D$. radiodurans $\mathrm{R} 1(\mathbf{)})$ is also shown. Each increment on the $y$ axis represents a tenfold reduction in viability. Error bars represent the range of values of duplicate experiments. quinones were extracted with chloroform/methanol $(2: 1$, $\mathrm{v} / \mathrm{v}$ ), purified via TLC and subsequently analysed by HPLC, as described previously (Collins \& Jones, 1981; Shin et al., 1996). For fatty acid methyl ester analysis, the strains were allowed to grow on R2A agar for $48 \mathrm{~h}$ at $30{ }^{\circ} \mathrm{C}$ and two loops of the well-grown cells were then harvested. Fatty acid methyl esters were prepared, separated and identified with the Sherlock Microbial Identification System (MIDI, Inc.) (Sasser, 1990). For measurement of the $\mathrm{G}+\mathrm{C}$ content of the chromosomal DNA, genomic DNA was extracted and purified with the Qiagen Genomic-tip system 100/G and then degraded enzymically into nucleosides; the $\mathrm{G}+\mathrm{C}$ content was determined as described by Mesbah et al. (1989) using reversed-phase HPLC.

Analysis of the peptidoglycan amino acids showed that strains $\mathrm{PB} 314^{\mathrm{T}}$ and $\mathrm{Ho}-08^{\mathrm{T}}$ contained L-ornithine, alanine, glycine and glutamic acid. From the two-dimensional TLC patterns of peptides in partial peptidoglycan hydrolysates, strains $\mathrm{PB} 314^{\mathrm{T}}$ and $\mathrm{Ho}-08^{\mathrm{T}}$ contained peptidoglycan type A3 $\beta$ (L-Orn-Gly-Gly). MK-8 was the predominant respiratory quinone of both strains $\mathrm{PB} 314^{\mathrm{T}}$ and $\mathrm{Ho}-08^{\mathrm{T}}$, like other Deinococcus species (Ferreira et al., 1997; Hirsch et al., 2004; Suresh et al., 2004; de Groot et al., 2005; Lai et al., 2006). They contained ribose and rhamnose in the cell wall. The predominant cellular fatty acids in the strains $\mathrm{PB} 314^{\mathrm{T}}$ and $\mathrm{Ho}-08^{\mathrm{T}}$ were hexadecenoic acid $\left(\mathrm{C}_{16: 1} \omega 7 c ; 49.9\right.$ and $51.8 \%$, respectively) and hexadecanoic acid $\left(\mathrm{C}_{16: 0} ; 32.3\right.$ and $37.3 \%$ ), which were also major fatty acids in most other Deinococcus species (Supplementary Table S1). However, some qualitative and quantitative differences in fatty acid composition could be observed between strains $\mathrm{PB} 314^{\mathrm{T}}$ and $\mathrm{Ho}-08^{\mathrm{T}}$ and their phylogenetically closest relatives. In particular, in contrast to $D$. grandis DSM $3963^{\mathrm{T}}, D$. indicus MTCC $4913^{\mathrm{T}}$ and $D$. radiodurans ATCC $13939^{\mathrm{T}}$, they produced $\mathrm{C}_{18: 0}$ but not $\mathrm{C}_{15: 1} \omega 6 c$ or $\mathrm{C}_{17: 1} \omega 6 c$ and contained smaller amounts of $\mathrm{C}_{17: 0}$. The fatty acid profile might be also useful for differentiation of the isolates. Strain $\mathrm{Ho}-08^{\mathrm{T}}$ differed from $\mathrm{PB} 314^{\mathrm{T}}$ by the absence of $\mathrm{C}_{15: 0}, \mathrm{C}_{15: 0}$ iso, $\mathrm{C}_{17: 0}$ iso, $\mathrm{C}_{15: 1}$ and $\mathrm{C}_{16: 1} \omega 9 c$. The $\mathrm{G}+\mathrm{C}$ contents of the genomic DNA of strains $\mathrm{PB} 314^{\mathrm{T}}$ and $\mathrm{Ho}-08^{\mathrm{T}}$ were respectively 68.3 and $68.4 \mathrm{~mol} \%$. These properties are consistent with the assignment of the organisms to the genus Deinococcus (Brooks \& Murray, 1981; Ferreira et al., 1997; Suresh et al., 2004; Lai et al., 2006).

The results of two-dimensional TLC analysis of polar lipids extracted from strains $\mathrm{PB} 314^{\mathrm{T}}$ and $\mathrm{Ho}-08^{\mathrm{T}}$ are shown in Supplementary Fig. S2. Based on their staining behaviour, the polar lipid profiles of the two strains consisted of various unknown phosphoglycolipids, glycolipids and polar lipids; unknown phospholipids were also detected in strain $\mathrm{Ho}-08^{\mathrm{T}}$. Polar lipid profiles of both strains were dominated by unknown phosphoglycolipid $\mathrm{PGL}_{2}$, which is consistent with previous results for Deinococcus species (Ferreira et al., 1997; de Groot et al., 2005; Lai et al., 2006; Weon et al., 2007). Moreover, strains $\mathrm{PB} 314^{\mathrm{T}}$ and $\mathrm{Ho}-08^{\mathrm{T}}$ showed unknown phosphoglycolipid $\mathrm{PGL}_{1}$, glycolipids $\mathrm{GL}_{1}$ 
and $\mathrm{GL}_{2}$ and unknown polar lipid $\mathrm{L}_{1}$, which were also detected in other Deinococcus species (Lai et al., 2006; Weon et al., 2007). At the same time, each of the two strains showed unique combinations of unknown polar lipids that might be useful for distinguishing them from each other and other members of the genus Deinococcus.

DNA-DNA hybridization experiments were performed between $\mathrm{PB} 314^{\mathrm{T}}$ and $\mathrm{Ho}-08^{\mathrm{T}}$ with the method described by Ezaki et al. (1989) using photobiotin-labelled DNA probes (Sigma) and microdilution wells (Greiner), with five replications for each sample. DNA-DNA relatedness of strain $\mathrm{PB} 314^{\mathrm{T}}$ to strain $\mathrm{Ho}-08^{\mathrm{T}}$ was $22 \%$, which is low enough to differentiate strain $\mathrm{PB} 314^{\mathrm{T}}$ and strain $\mathrm{Ho}-08^{\mathrm{T}}$ as members of different species (Wayne et al., 1987).

$16 \mathrm{~S}$ rRNA gene sequence comparison showed that strains $\mathrm{PB} 314^{\mathrm{T}}$ and $\mathrm{Ho}^{-08^{\mathrm{T}}}$ exhibited closest phylogenetic affinities to Deinococcus species. Phylogenetic analysis based on 16S rRNA gene sequences shows that the two strains fell within the radiation of the cluster comprising Deinococcus species and were most closely related to $D$. grandis DSM $3963^{\mathrm{T}}, D$. indicus $\mathrm{Wt} / 1 \mathrm{a}^{\mathrm{T}}$ and $D$. radiodurans DSM $20539^{\mathrm{T}}$. The presence of peptidoglycan type $\mathrm{A} 3 \beta$ and MK-8 as the major lipoquinone, the polar lipid patterns, fatty acid compositions and other characteristics confirm their assignment to the genus Deinococcus. Although strains $\mathrm{PB} 314^{\mathrm{T}}$ and $\mathrm{Ho}-08^{\mathrm{T}}$ showed all the typical characters of the genus Deinococcus, they differed significantly from their closest phylogenetic relatives with respect to radiation resistance (Fig. 2), the combination of unknown polar lipids (Supplementary Fig. S2), the proportions of some fatty acids (Supplementary Table S1) and a number of other physiological and chemotaxonomic characteristics (Table 1). Furthermore, it is evident from the genotypic and phenotypic data that the two isolates could be clearly differentiated from each other. On the basis of these results, strains $\mathrm{PB} 314^{\mathrm{T}}$ and $\mathrm{Ho}-08^{\mathrm{T}}$ are proposed as the type strains of two novel species of the genus Deinococcus, for which the names Deinococcus aquaticus sp. nov. and Deinococcus caeni sp. nov., respectively, are proposed.

\section{Description of Deinococcus aquaticus sp. nov.}

Deinococcus aquaticus (a.qua'ti.cus. L. masc. adj. aquaticus living, growing or found in or by water, aquatic).

Cells are Gram-negative, non-spore-forming rods, 2.5$3.0 \mu \mathrm{m}$ long. Positive for catalase, $\beta$-galactosidase and hydrolysis of starch. Negative for urease, indole production, nitrate reduction and hydrolysis of DNA, CMcellulose, lipid (olive oil) and xylan. Grows on R2A at $\mathrm{pH}$ 6.0-9.5. Does not require $\mathrm{NaCl}$ for growth; can tolerate $3 \%(\mathrm{w} / \mathrm{v}) \mathrm{NaCl}$. The following substrates are utilized for growth as sole carbon sources: D-glucose, glycogen, maltose, $N$-acetyl-D-glucosamine, L-proline and sucrose. The following substrates are not utilized for growth: acetate, adipate, L-alanine, caprate, citrate, D-fucose, 4hydroxybenzoate, 3-hydroxybenzoate, DL-3-hydroxybuty- rate, inositol, itaconate, 2-ketogluconate, 5-ketogluconate, lactate, malonate, phenylacetate, propionate, L-rhamnose, D-ribose, L-serine, suberate and valerate. MK-8 is the predominant lipoquinone. The major fatty acids are $\mathrm{C}_{16: 1}$ and $\mathrm{C}_{16: 0}$. Ornithine and glycine are present in the peptidoglycan. Cell wall contains ribose and rhamnose. The $\mathrm{G}+\mathrm{C}$ content of the genomic DNA of the type strain is $68.3 \mathrm{~mol} \%$.

The type strain, PB314 ${ }^{\mathrm{T}}\left(=\mathrm{KCTC} 12552^{\mathrm{T}}=\mathrm{NBRC}\right.$ $101311^{\mathrm{T}}$ ), was isolated from a freshwater stream that flows into the River Gapcheon near KAIST in Daejeon City, South Korea.

\section{Description of Deinococcus caeni sp. nov.}

Deinococcus caeni (cae'ni. L. gen. neut. n. caeni of sludge).

Cells are Gram-negative, non-spore-forming rods, 2.0$3.0 \mu \mathrm{m}$ long. Positive for catalase, $\beta$-galactosidase and hydrolysis of starch. Negative for urease, oxidase, indole production, nitrate reduction and hydrolysis of DNA, CMcellulose, lipid (olive oil) and xylan. Grows on R2A at $\mathrm{pH}$ 6.5-9.5. Does not require $\mathrm{NaCl}$ for growth; can tolerate $3 \%(\mathrm{w} / \mathrm{v}) \mathrm{NaCl}$. The following substrates are utilized for growth as sole carbon sources: D-glucose, glycogen, maltose, $\mathrm{N}$-acetyl-D-glucosamine, L-proline and sucrose. The following substrates are not utilized for growth: acetate, adipate, L-alanine, caprate, citrate, D-fucose, 4hydroxybenzoate, 3-hydroxybenzoate, DL-3-hydroxybutyrate, inositol, itaconate, 2-ketogluconate, 5-ketogluconate, lactate, malonate, phenylacetate, propionate, L-rhamnose, D-ribose, L-serine, suberate and valerate. MK- 8 is the predominant lipoquinone. The major fatty acids are $\mathrm{C}_{16: 1}$ and $\mathrm{C}_{16: 0}$. Ornithine and glycine are present in the peptidoglycan. Cell wall contains ribose and rhamnose. The $\mathrm{G}+\mathrm{C}$ content of the genomic DNA of the type strain is $68.4 \mathrm{~mol} \%$.

The type strain, Ho- $08^{\mathrm{T}} \quad\left(=\mathrm{KCTC} 12553^{\mathrm{T}}=\mathrm{NBRC}\right.$ $101312^{\mathrm{T}}$ ), was isolated from activated sludge in a wastewater-treatment plant that receives leachate from a landfill site in Daejeon City, South Korea.

\section{Acknowledgements}

This work was supported by the 21C Frontier Microbial Genomics and Application Center Program, Ministry of Science \& Technology (grant MG05-0101-4-0), Republic of Korea.

\section{References}

Atlas, R. M. (1993). Handbook of Microbiological Media. Edited by L. C. Parks. Boca Raton, FL: CRC Press.

Battista, J. R. \& Rainey, F. A. (2001). Order I. Deinococcales Rainey, Nobre, Schumann, Stackebrandt and da Costa 1997, 513 ${ }^{\mathrm{VP}}$. In Bergey's Manual of Systematic Bacteriology, 2nd edn, vol. 1, p. 395. Edited by D. R. Boone, R. W. Castenholz \& G. M. Garrity. New York: Springer. 
Battista, J. R., Earl, A. M. \& Park, M.-J. (1999). Why is Deinococcus radiodurans so resistant to ionizing radiation? Trends Microbiol $\mathbf{7}$, 362-365.

Brooks, B. W. \& Murray, R. G. E. (1981). Nomenclature for "Micrococcus radiodurans" and other radiation-resistant cocci: Deinococcaceae fam. nov. and Deinococcus gen. nov., including five species. Int J Syst Bacteriol 31, 353-360.

Buck, J. D. (1982). Nonstaining (KOH) method for determination of Gram reactions of marine bacteria. Appl Environ Microbiol 44, 992-993.

Collins, M. D. \& Jones, D. (1981). Distribution of isoprenoid quinone structural types in bacteria and their taxonomic implications. Microbiol Rev 45, 316-354.

de Groot, A., Chapon, V., Servant, P., Christen, R., Fischer-Le Saux, M., Sommer, S. \& Heulin, T. (2005). Deinococcus deserti sp. nov., a gammaradiation-tolerant bacterium isolated from the Sahara Desert. Int J Syst Evol Microbiol 55, 2441-2446.

Ezaki, T., Hashimoto, Y. \& Yabuuchi, E. (1989). Fluorometric deoxyribonucleic acid-deoxyribonucleic acid hybridization in microdilution wells as an alternative to membrane filter hybridization in which radioisotopes are used to determine genetic relatedness among bacterial strains. Int J Syst Bacteriol 39, 224-229.

Felsenstein, J. (1985). Confidence limits on phylogenies: an approach using the bootstrap. Evolution 39, 783-791.

Felsenstein, J. (1989). PHYLIP - phylogeny inference package (version 3.2). Cladistics 5, 164-166.

Ferreira, A. C., Nobre, M. F., Rainey, F. A., Silva, M. T., Wait, R., Burghardt, J., Chung, A. P. \& da Costa, M. S. (1997). Deinococcus geothermalis sp. nov. and Deinococcus murrayi sp. nov., two extremely radiation-resistant and slightly thermophilic species from hot springs. Int J Syst Bacteriol 47, 939-947.

Fitch, W. M. (1971). Toward defining the course of evolution: minimum change for a specific tree topology. Syst Zool 20, 406-416.

Hall, T. A. (1999). BioEdit: a user-friendly biological sequence alignment editor and analysis program for Windows 95/98/NT. Nucleic Acids Symp Ser 41, 95-98.

Hirsch, P., Gallikowski, C. A., Siebert, J., Peissl, K., Kroppenstedt, R., Schumann, P., Stackebrandt, E. \& Anderson, R. (2004). Deinococcus frigens sp. nov., Deinococcus saxicola sp. nov., and Deinococcus marmoris sp. nov., low temperature and draught-tolerating, UVresistant bacteria from continental Antarctica. Syst Appl Microbiol 27, 636-645.

Im, W.-T., Kang, M.-S., Park, H.-Y., Kim, M.-K. \& Lee, S.-T. (2003) Culturable bacterial strain's diversity of environmental samples. In Proceedings of the International Meeting of the Federation of Korean Microbiological Societies, abstract B4023, p. 165. Seoul: Federation of Korean Microbiological Societies.

Kim, M. K., Im, W.-T., Ohta, H., Lee, M. \& Lee, S.-T. (2005). Sphingopyxis granuli sp. nov., a $\beta$-glucosidase-producing bacterium in the family Sphingomonadaceae in $\alpha-4$ subclass of the Proteobacteria. J Microbiol 43, 152-157.

Kimura, M. (1983). The Neutral Theory of Molecular Evolution. Cambridge: Cambridge University Press.

Kouker, G. \& Jaeger, K.-E. (1987). Specific and sensitive plate assay for bacterial lipase. Appl Environ Microbiol 53, 211-213.

Kumar, S., Tamura, K. \& Nei, M. (2004). MEGA3: integrated software for molecular evolutionary genetics analysis and sequence alignment. Brief Bioinform 5, 150-163.
Lai, W. A., Kämpfer, P., Arun, A. B., Shen, F. T., Huber, B., Rekha, P. D. \& Young, C. C. (2006). Deinococcus ficus sp. nov., isolated from the rhizosphere of Ficus religiosa L. Int J Syst Evol Microbiol 56, 787-791.

Mattimore, V. \& Battista, J. R. (1996). Radioresistance of Deinococcus radiodurans: functions necessary to survive ionizing radiation are also necessary to survive prolonged desiccation. J Bacteriol 178, 633-637.

Mesbah, M., Premachandran, U. \& Whitman, W. B. (1989). Precise measurement of the $\mathrm{G}+\mathrm{C}$ content of deoxyribonucleic acid by highperformance liquid chromatography. Int J Syst Bacteriol 39, 159-167.

Oyaizu, H., Stackebrandt, E., Schleifer, K. H., Ludwig, W., Pohla, H., Ito, H., Hirata, A., Oyaizu, Y. \& Komagata, K. (1987). A radiationresistant rod-shaped bacterium, Deinobacter grandis gen. nov., sp. nov., with peptidoglycan containing ornithine. Int J Syst Bacteriol 37, 62-67.

Rainey, F. A., Nobre, M. F., Schumann, P., Stackebrandt, E. \& da Costa, M. S. (1997). Phylogenetic diversity of the deinococci as determined by $16 \mathrm{~S}$ ribosomal DNA sequence comparison. Int J Syst Bacteriol 47, 510-514.

Rainey, F. A., Ray, K., Ferreira, M., Gatz, B. Z., Nobre, M. F., Bagaley, D., Rash, B. A., Park, M. J., Earl, A. M. \& other authors (2005). Extensive diversity of ionizing-radiation-resistant bacteria recovered from Sonoran Desert soil and description of nine new species of the genus Deinococcus obtained from a single soil sample. Appl Environ Microbiol 71, 5225-5235.

Saitou, N. \& Nei, M. (1987). The neighbor-joining method: a new method for reconstructing phylogenetic trees. Mol Biol Evol 4, 406425.

Sasser, M. (1990). Identification of bacteria by gas chromatography of cellular fatty acids, MIDI Technical Note 101. Newark, DE: MIDI Inc.

Schleifer, K. H. \& Kandler, O. (1972). Peptidoglycan types of bacterial cell walls and their taxonomic implications. Bacteriol Rev 36, 407-477.

Shashidhar, R. \& Bandekar, J. R. (2006). Deinococcus mumbaiensis sp. nov., a radiation-resistant pleomorphic bacterium isolated from Mumbai, India. FEMS Microbiol Lett 254, 275-280.

Shin, Y. K., Lee, J.-S., Chun, C. O., Kim, H.-J. \& Park, Y.-H. (1996). Isoprenoid quinone profiles of the Leclercia adecarboxylata KCTC $1036^{\mathrm{T}}$. J Microbiol Biotechnol 6, 68-69.

Staneck, J. L. \& Roberts, G. D. (1974). Simplified approach to identification of aerobic actinomycetes by thin-layer chromatography. Appl Microbiol 28, 226-231.

Suresh, K., Reddy, G. S., Sengupta, S. \& Shivaji, S. (2004). Deinococcus indicus sp. nov., an arsenic-resistant bacterium from an aquifer in West Bengal, India. Int J Syst Evol Microbiol 54, 457-461.

Ten, L. N., Im, W.-T., Kim, M.-K., Kang, M.-S. \& Lee, S.-T. (2004). Development of a plate technique for screening of polysaccharidedegrading microorganisms by using a mixture of insoluble chromogenic substrates. J Microbiol Methods 56, 375-382.

Thompson, J. D., Gibson, T. J., Plewniak, F., Jeanmougin, F. \& Higgins, D. G. (1997). The CLUSTAL_X windows interface: flexible strategies for multiple sequence alignment aided by quality analysis tools. Nucleic Acids Res 25, 4876-4882.

Wayne, L. G., Brenner, D. J., Colwell, R. R., Grimont, P. A. D., Kandler, O., Krichevsky, M. I., Moore, L. H., Moore, W. E. C., Murray, R. G. E. \& other authors (1987). International Committee on Systematic Bacteriology. Report of the ad hoc committee on reconciliation of approaches to bacterial systematics. Int J Syst Bacteriol 37, 463-464.

Weon, H. Y., Kim, B. Y., Schumann, P., Son, J. A., Jang, J., Go, S. J. \& Kwon, S. W. (2007). Deinococcus cellulosilyticus sp. nov., isolated from air. Int J Syst Evol Microbiol 57, 1685-1688. 